\title{
AKUMULASI MIKROPLASTIK PADA SPESIES IKAN EKONOMIS PENTING DI PERAIRAN PULAU BARRANGLOMPO, MAKASSAR
}

\section{MICROPLASTIC ACCUMULATION IN ECONOMICALLY IMPORTANT FISH SPECIES FROM BARRANGLOMPO ISLAND WATERS, MAKASSAR}

\author{
Rahmat Sawalman $^{1}$, Neviaty Putri Zamani2 ${ }^{2 *}$, Shinta Werorilangi ${ }^{3}$, \& \\ Meutia Samira Ismet ${ }^{2}$ \\ ${ }^{1}$ Program Studi Ilmu Kelautan, Sekolah Pascasarjana, IPB University, Bogor, 16680, Indonesia \\ ${ }^{2}$ Departemen Ilmu dan Teknologi Kelautan, Fakultas Perikanan dan Ilmu Kelautan, \\ IPB University, Bogor, 16680, Indonesia \\ ${ }^{3}$ Departemen Ilmu Kelautan, Fakultas Ilmu Kelautan dan Perikanan, \\ Universitas Hasanuddin, Makassar, 90245, Indonesia \\ *E-mail: neviaty@apps.ipb.ac.id
}

\begin{abstract}
Microplastics (MPs) have been found in various marine compartments especially in fish, and there is limited information regarding the accumulation of MPs in fish organs. Therefore, this study aimed to investigate the presence of microplastics in economically important fish organs (Hemiramphus far, Siganus virgatus, and Lethrinus lentjan) at Barranglompo Island Waters, Makassar, and also to identify the characteristics of microplastics including color, shape, and size. Each organ was extracted using KOH 20\% and the MPs characteristics were observed visually using a stereomicroscope. The result showed that MPs were found in gills, gastrointestinal tract, and flesh of three fish species. The detection rate of MPs in H. far, S. virgatus, and L. lentjan was 100\%, 100\%, and $82 \%$, respectively. The most common MP colour was blue, the shape was predominantly line, and the most abundant size range was 1-5 $\mathrm{mm}$. Further studies are needed to investigate the accumulation of MPs in fish organs experimentally in the laboratory.
\end{abstract}

Keywords: Barranglompo Island, fish health index, fish organs, microplastic

\begin{abstract}
ABSTRAK
Mikroplastik (MP) telah ditemukan di berbagai lingkungan laut khususnya pada ikan, dan informasi terkait akumulasi mikroplastik pada organ-organ ikan masih sangat terbatas. Penelitian ini bertujuan untuk membuktikan keberadaan mikroplastik pada organ insang, saluran pencernaan, dan daging ikan ekonomis penting (Hemiramphus far, Siganus virgatus, dan Lethrinus lentjan) di perairan Pulau Barranglompo, Makassar, serta mengidentifikasi karakteristik mikroplastik meliputi warna, bentuk, dan ukuran. Setiap organ diekstraksi menggunakan $\mathrm{KOH} 20 \%$ dan pengamatan karakteristik MP dilakukan secara visual menggunakan mikroskop stereo. Hasil penelitian menunjukkan bahwa mikroplastik ditemukan di insang, saluran pencernaan, dan daging dari ketiga spesies ikan. Tingkat deteksi mikroplastik pada masing-masing $H$. far, S. virgatus, dan L. lentjan adalah $100 \%, 100 \%$, dan $82 \%$. Karakteristik warna mikroplastik didominasi oleh biru, bentuk mikroplastik didominasi oleh line, dan kisaran ukuran mikroplastik didominasi 1-5 $\mathrm{mm}$. Penelitian lebih lanjut perlu dilakukan untuk melihat akumulasi mikroplastik pada setiap organ secara eksperimental di laboratorium.
\end{abstract}

Kata Kunci: indeks kesehatan ikan, mikroplastik, organ ikan, Pulau Barranglompo

\section{PENDAHULUAN}

Pengelolaan sampah plastik yang tidak tepat dan tidak terkontrol telah menimbulkan berbagai permasalahan di lingkungan laut. Plastik tersusun dari material polimer sintetik yang digunakan di dalam berbagai kebutuhan manusia seharihari. Namun, sifatnya yang tidak dapat terurai di lingkungan menyebabkan terjadi- 
nya akumulasi pada biota (GESAMP, 2015). Secara global, sampah laut jenis plastik terdistribusi di berbagai lingkungan laut seperti garis pantai, permukaan laut dan dasar laut yang mencapai 95\% dari total komponen sampah laut yang terakumulasi (Galgani, 2015). Pada tahun 2016, Amerika Serikat menduduki posisi pertama sebagai negara yang menyumbang sampah plastik ke perairan laut dunia dengan estimasi mencapai 42 juta metrik ton, sedangkan Indonesia menduduki peringkat keenam dengan estimasi sampah plastik mencapai 9 juta metrik ton (Law et al., 2020).

Pulau Barranglompo merupakan salah satu pulau di Kepulauan Spermonde yang terletak di pesisir barat laut Kota Makassar. Pulau ini diketahui memiliki potensi ekologi dan ekonomi yang tinggi (Nurdin et al., 2015). Namun, pertambahan penduduk setiap tahunnya di pulau ini mengakibatkan permasalahan pengelolaan sampah yang tidak terkontrol sehingga berdampak terhadap produktivitas laut di perairan pulau ini. Pada tahun 2018, jumlah penduduk di pulau ini mencapai 4731 jiwa dengan kepadatan penduduk sebesar $2088 \mathrm{jiwa} / \mathrm{km}^{2}$ (BPS Kota Makassar, 2019). Tingginya aktifitas antropogenik di pulau ini mengakibatkan sampah laut jenis plastik ditemukan mendominasi di perairan (Mandala, 2016). Selain itu, permasalahan terkait pengelolaan sampah yang tidak tepat di Kota Makassar menjadi salah satu sumber utama pencemaran sampah plastik di perairan sekitar. World Bank (2018) melaporkan sampah tidak tertangani yang dihasilkan di Kota Makassar sebesar 95,5 ton/hari dengan persentase sampah plastik mencapai $44,7 \%$ dan bersumber dari sampah rumah tangga. Tingginya persentase sampah plastik tersebut akan memberikan ancaman terhadap produktivitas laut di pulau-pulau kecil.

Sampah plastik di perairan laut akan mengalami fragmentasi akibat proses fisik, mekanik, kimia, dan biologi menjadi partikel yang berukuran lebih kecil yang disebut mikroplastik (<5 mm) (Avio et al., 2017).
Penelitian sebelumnya melaporkan adanya akumulasi mikroplastik di perairan Kota Makassar (Afdal et al., 2019; Tahir et al., 2019b; Wicaksono et al., 2020). Oleh karena itu, ikan ekonomis penting yang hidup di perairan Pulau Barranglompo rentan akan pencemaran mikroplastik. Dikarenakan ukurannya yang sangat kecil, mikroplastik di perairan laut dapat dengan mudah untuk terinternalisasi ke tubuh organisme laut (Nie et al., 2019). Translokasi mikroplastik dapat terjadi di dalam organ insang, saluran pencernaan, daging (Barboza et al., 2019). Akumulasi mikroplastik juga ditemukan pada organisme bentik di perairan Kepulauan Spermonde, Makassar (Tahir et al., 2019a) dan juga pada ikan konsumsi yang dikumpulkan di Pasar Ikan Paotere, Makassar (Rochman et al., 2015). Akumulasi mikroplastik di perairan laut tentunya memberikan ancaman terhadap kesehatan ikan-ikan ekonomis penting. Penelitian mengenai hubungan antara mikroplastik dan parameter biologis ikan masih sangat terbatas. Menurut Critchell dan Hoogenboom (2018), status kesehatan ikan dapat diukur melalui indeks hepatosomatik (IHS) dan faktor kondisi relatifya (Kn). Nilai IHS yang tinggi dan nilai $\mathrm{Kn}$ yang rendah menunjukkan adanya dampak negatif yang ditimbulkan oleh mikroplastik terhadap kesehatan ikan (Morado et al., 2017; Maes et al., 2020). Dikarenakan perpindahan mikroplastik dapat terjadi melalui rantai makanan, akumulasi mikroplastik pada ikan juga berpotensi memberikan efek negatif terhadap manusia yang mengonsumsinya (Miller et al., 2020).

Bagaimanapun, penelitian lebih lanjut mengenai akumulasi mikroplastik pada ikanikan ekonomis penting di perairan Pulau Barranglompo perlu dilakukan mengingat tingginya produktivitas perikanan di wilayah ini dan juga belum adanya kajian terkait akumulasi mikroplastik di setiap organ berbeda pada ikan ekonomis penting di pulau ini. Selain itu, studi mengenai hubungan antara keberadaan mikroplastik dengan 
berbagai parameter biologis kesehatan ikan seperti indeks hepatosomatik (IHS) dan faktor kondisi (Kn) masih sangat jarang dilakukan. Tanpa adanya kajian lebih jauh mengenai bagaimana mikroplastik memengaruhi fisiologis organisme, sangat sulit untuk menentukan dampak skala besar mikroplastik sebagai salah satu bahan pencemar di perairan laut. Oleh karena itu, penelitian ini bertujuan untuk membuktikan keberadaan mikroplastik di insang, saluran pencernaan dan daging pada ikan-ikan ekonomis penting yaitu Hemiramphus far (julung-julung), Siganus virgatus (baronang) dan Lethrinus lentjan (katamba) di Pulau Barranglompo, mengidentifikasi karakteristik mikroplastik, serta penilaian status kesehatan ikan yang terpapar mikroplastik meliputi Indeks Hepatosomatik (IHS) dan Faktor
Kondisi Relatif (Kn). Penelitian ini dilakukan sebagai upaya untuk meningkatkan manajemen dan perlindungan lingkungan pesisir serta menjamin keamanan pangan (food safety) yang bersumber dari laut.

\section{METODE PENELITIAN}

\subsection{Waktu dan Lokasi Penelitian}

Penelitian ini dilaksanakan pada bulan Juli-November 2020. Pengambilan sampel dilakukan di Pulau Barranglompo yang terletak pada $119^{\circ} 19^{\prime} 44^{\prime \prime}$ dan $05^{\circ} 2^{\prime}$ ' 54", Kelurahan Sangkarrang, Kecamatan Ujung Tanah, Makassar (Gambar 1). Pengamatan mikroplastik pada sampel dilakukan di Laboratorium Ekotoksikologi Laut, Fakultas Ilmu Kelautan dan Perikanan, Universitas Hasanuddin, Makassar.

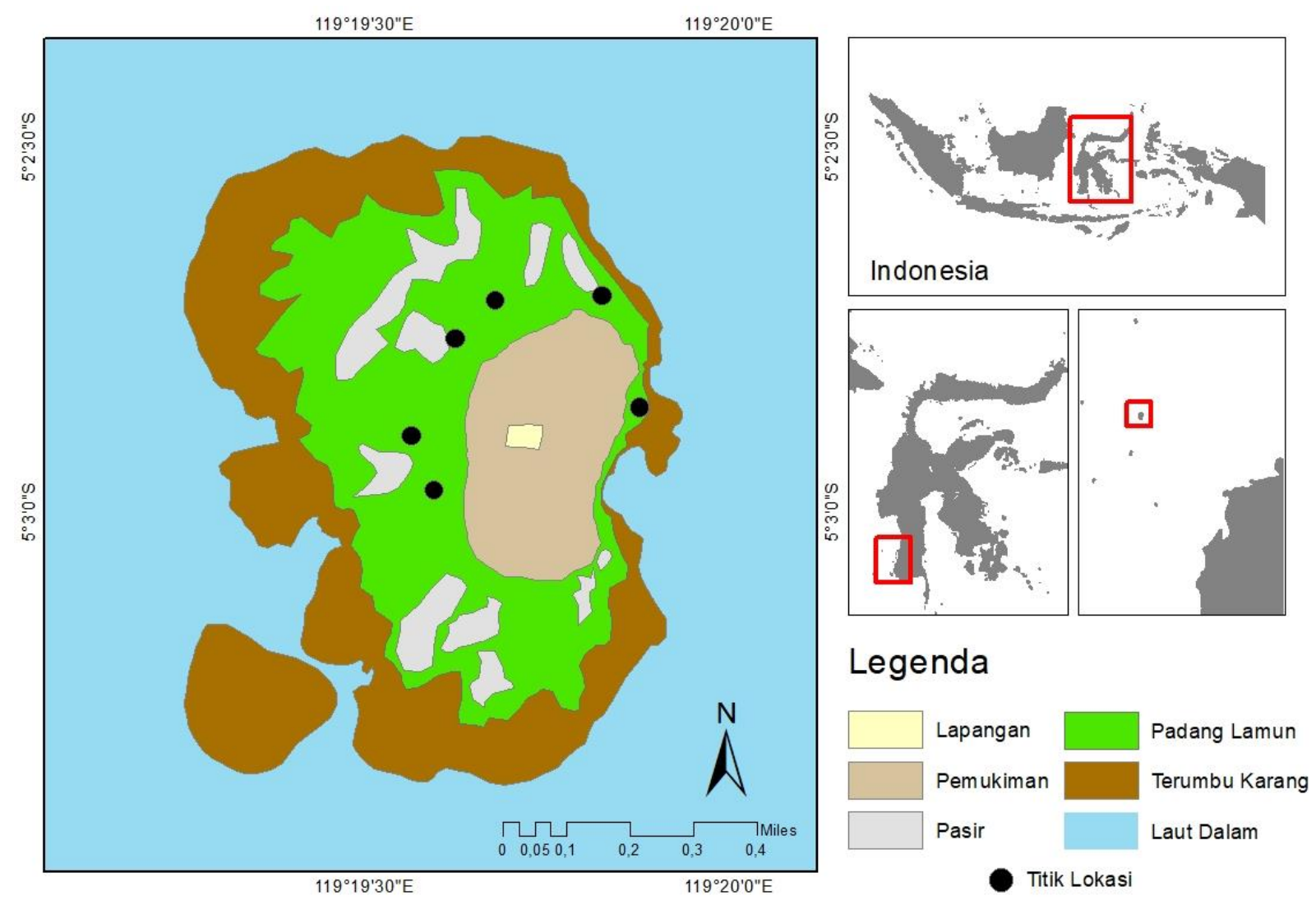

Gambar 1. Peta lokasi pengambilan sampel di Pulau Barranglompo, Kepulauan Spermonde, Sulawesi Selatan. 


\subsection{Pengumpulan Sampel Ikan}

Pengumpulan sampel ikan di lapangan dilakukan pada bulan Juli 2020 dengan kondisi angin musim timur (musim kemarau). Pemilihan waktu tersebut mengacu pada penelitian sebelumnya oleh Rasyid et al. (2014) yang melaporkan bahwa waktu tersebut merupakan salah satu waktu yang ideal untuk dilakukan penangkapan ikan di perairan Makassar. Pengumpulan sampel ikan dilakukan selama satu hari dimulai pada pukul 09.00-17.00 WITA. Pengambilan sampel ikan dilakukan secara acak (random sampling method) pada enam titik lokasi di area padang lamun Pulau Barranglompo, Makassar (Gambar 1) dengan menggunakan seine net berukuran $1 \mathrm{~m} \times 10 \mathrm{~m}$ dengan diameter mata jaring $5 \mathrm{~mm}$ (Simanjuntak et al., 2020).

Berdasarkan hasil sampling di lapangan, terdapat tiga jenis ikan yang melimpah meliputi $H$. far $(\mathrm{N}=25)$, S. virgatus $(\mathrm{N}=25)$ dan L. lentjan $(\mathrm{N}=50)$. Total sampel keseluruhan sebanyak 100 individu ( $\mathrm{N}=100)$. Sampel ikan yang ditangkap dimasukkan ke dalam kantong sampel dan ditempatkan di dalam kotak pendingin berisi es beku agar sampel tetap dalam kondisi segar.

\subsection{Pengukuran Morfometrik dan Proses Ekstraksi Organ Ikan}

Pengukuran morfometrik berupa panjang total dan bobot tubuh dilakukan pada sampel ikan. Selain itu, setiap organ insang, saluran pencernaan, dan daging dilakukan penimbangan bobot organ. Kelimpahan mikroplastik pada insang dan daging dinyatakan dalam satuan MP per bobot organ (MP/gr), sedangkan kelimpahan mikroplastik pada saluran pencernaan dinyatakan dalam MP/individu. Hal tersebut dikarenakan isi dari saluran pencernaan ikan bersifat fluktuatif, sedangkan pada insang dan daging bersifat konstan.

Setiap organ dimasukkan ke dalam botol sampel yang berisi larutan $\mathrm{KOH} 224$ gr/L (224 gr padatan $\mathrm{KOH}$ dalam 1 liter aquades) lalu didiamkan pada suhu ruangan selama 14 hari. Metode ekstraksi ini dimodifikasi dari Foekema et al. (2013) dan Munno et al. (2017), sebagai metode yang paling efisien untuk melarutkan material biologis dari jaringan ikan.

\subsection{Identifikasi Karakteristik dan Polimer Mikroplastik}

Setiap mikroplastik $(1 \mu \mathrm{m}-5 \mathrm{~mm})$ yang ditemukan kemudian dilakukan pengamatan karakteristik secara visual meliputi warna, bentuk, dan ukuran menggunakan mikroskop stereo (Euromex SB1902) (Tahir et al., 2019b). Pengujian lebih lanjut terkait jenis polimer mikroplastik dilakukan menggunakan Fourier Transform Infrared (FTIR) dengan aksesoris Attenuated Total Reflectance (ATR). Mikroplastik yang akan diuji dipilih berdasarkan karakteristik yang berbeda $(\mathrm{N}=6)$ (mewakili warna dan bentuk yang berbeda).

\subsection{Pencegahan Kontaminasi dan Quality Control}

Pencegahan kontaminasi mikroplastik di lapangan dilakukan dengan membersihkan semua peralatan yang digunakan saat pengambilan sampel ikan di lapangan, menggunakan gloves, dan menempatkan sampel pada kotak pendingin dalam keadaan tertutup (Lusher et al., 2017). Semua peralatan yang akan digunakan di laboratorium juga harus dalam keadaan steril dengan cara dibersihkan dan dibilas menggunakan aquades. Selama pengerjaan sampel di laboratorium, sampel harus berada di tempat yang steril dan dijauhkan dari hal-hal yang dapat menyebabkan kontaminasi silang di dalam ruangan seperti penggunaan air conditioner (AC) di dalam ruangan. Jas laboratorium selama pengerjaan sampel harus terbuat dari katun (serat alami) serta harus menggunakan masker dan gloves selama pengerjaan sampel.

Prosedur blanko merupakan tahapan yang sangat penting untuk mengetahui banyaknya kontaminasi mikroplastik dari udara dan peralatan yang digunakan selama 
penelitian berlangsung. Pada tahap preparasi sampel ikan, sebanyak lima blanko digunakan untuk menghitung banyaknya kontaminasi mikroplastik selama proses pembedahan ikan hingga proses ekstraksi sampel dengan menambahkan larutan $\mathrm{KOH}$ dengan konsentrasi $224 \mathrm{gr} / \mathrm{L}$ sebanyak $50 \mathrm{ml}$ ke dalam botol sampel kosong. Pada tahap identifikasi mikroplastik, sebanyak 31 blanko digunakan untuk menghitung banyaknya kontaminasi selama pengamatan mikroplastik secara visual menggunakan mikroskop stereo dengan menambahkan larutan $\mathrm{KOH}$ ke dalam cawan petri kosong dan dibiarkan terbuka selama proses pengamatan berlangsung. Prosedur blanko ini mengacu pada penelitian sebelumnya oleh Mizraji et al. (2017) dan Digka et al. (2018).

\subsection{Penilaian Indeks Hepatosomatik (IHS)}

Indeks Hepatosomatik (IHS) digunakan sebagai salah satu indikator kesehatan ikan. Pengambilan sampel organ hati dilakukan pada seluruh sampel $(\mathrm{N}=100)$. Perhitungan IHS mengacu pada Gonino et al. (2019):

$\mathrm{HSI}=\frac{\mathrm{Bh}}{\mathrm{Bt}} \mathrm{x} 100 \%$

Keterangan: $I H S=$ Indeks Hepatosomatik (\%); $B h=$ Bobot hati (gr); $B t=$ Bobot tubuh (gr).

\subsection{Penilaian Faktor Kondisi Relatif (Kn)}

Faktor kondisi merupakan indikator yang menyatakan kemontokan ikan secara kualitas dan dapat menentukan respons ikan terhadap variabel seperti status gizi, efek patogen dan paparan senyawa kimia toksik (Morado et al., 2017). Perhitungan faktor kondisi relatif mengacu pada Le cren (1951):

$\mathrm{Kn}=\frac{\mathrm{w}}{\mathrm{w}^{*}}$

Keterangan: $K n=$ Faktor kondisi relatif; $W=$ Bobot tubuh tertimbang (gr); $W^{*}=$ Bobot tubuh terhitung (gr).

\subsection{Analisis Data}

Pengukuran dan visualisasi ukuran mikroplastik menggunakan aplikasi ImageJ versi 1.4551. Pengujian statistik data perbandingan kelimpahan mikroplastik pada ikan, penilaian kesehatan ikan, serta penyajian histogram dan grafik menggunakan aplikasi GraphPad Prism 9.0.0. Pengujian data dilakukan pada tingkat signifikansi $5 \%$. Hasil uji normalitas data kelimpahan mikroplastik antara spesies ikan di setiap organnya menunjukkan hasil yang tidak terdistribusi normal, sehingga analisis dilanjutkan dengan menggunakan uji non-parametrik Kruskal Wallis untuk membandingkan kelimpahan mikroplastik pada spesies ikan berbeda di setiap organnya. Apabila hasil menunjukkan nilai yang signifikan, maka diuji lanjut menggunakan uji Dunn's Multiple Comparison. Hasil uji normalitas data IHS dan Kn pada masing-masing spesies ikan menunjukkan hasil yang terdistribusi normal, sehingga analisis dilanjutkan menggunakan uji parametrik Independent Sample t-Test untuk membandingkan nilai indeks kesehatan ikan pada ikan yang tedeteksi dan tidak terdeteksi MP pada masing-masing nilai IHS dan $\mathrm{Kn}$.

\section{HASIL DAN PEMBAHASAN}

\subsection{Kelimpahan Mikroplastik pada Spesies Ikan Berbeda}

Hasil prosedur blanko diperoleh ratarata kontaminasi mikroplastik sebesar $0,75 \pm$ 0,84 MP/blanko. Nilai kontaminasi yang ditemukan hanya berpengaruh $3,36 \%$ pada hasil pengamatan, sehingga kontaminasi dapat diabaikan. Pada penelitian ini, persentase paparan mikroplastik yang ditemukan adalah $100 \%$ pada $H$. far, $100 \%$ pada $S$. virgatus, dan $82 \%$ pada L. lentjan. Tingkat deteksi mikroplastik pada penelitian ini tergolong lebih tinggi jika dibandingkan penelitian sebelumnya oleh Barboza et al. (2019) dengan rata-rata tingkat deteksi $42 \%$ 
mikroplastik pada ikan Dicentrarchus labrax, pada Trachurus trachurus, dan $62 \%$ pada Scomber colias. Secara spesifik, tingkat deteksi mikroplastik pada ketiga organ ikan H. far mencapai $72 \%$ pada insang, $72 \%$ pada saluran pencernaan, dan $68 \%$ pada daging. Pada ikan S. virgatus mencapai $80 \%$ pada insang, $100 \%$ pada saluran pencernaan, dan $32 \%$ pada daging, serta pada ikan L. lentjan mencapai $52 \%$ pada insang, $60 \%$ pada saluran pencernaan, dan $24 \%$ pada daging.

Rata-rata kelimpahan MP yang terdeteksi di insang pada ketiga spesies ikan meliputi $H$. far $(1,514 \pm 0,314 \mathrm{MP} / \mathrm{gr}), S$. virgatus $(5,976 \pm 1,347 \mathrm{MP} / \mathrm{gr})$, dan $L$. lentjan $(1,412 \pm 0,238 \mathrm{MP} / \mathrm{gr})$. Pada saluran pencernaan meliputi $H$. far $(2,480 \pm 0,656$ MP/individu), $S$. virgatus $(19,000 \pm 2,844$ MP/individu), dan L. lentjan (0,980 $\pm 0,147$ MP/individu). Pada daging meliputi $H$. far $(0,060 \pm 0,011 \mathrm{MP} / \mathrm{gr}), S$. virgatus $(0,098 \pm$ $0,033 \mathrm{MP} / \mathrm{gr})$, dan L. lentjan $(0,047 \pm 0,012$ MP/gr). Rata-rata kelimpahan MP di insang dan saluran pencernaan pada penelitian ini lebih tinggi sedangkan di daging lebih rendah dibandingkan penelitian sebelumnya oleh Barboza et al. (2019), dengan rata-rata kelimpahan MP pada ikan Dichentrachus labrax $(\mathrm{N}=50)$ sebesar $0,8 \pm 1,4 \mathrm{MP} / \mathrm{gr}$ pada insang, 1,3 $\pm 2,5 \mathrm{MP} /$ individu pada saluran pencernaan, 0,4 $\pm 0,7 \mathrm{MP} / \mathrm{gr}$ pada daging.

Berdasarkan rata-rata kelimpahan mikroplastik di setiap organ ikan yang diamati, terdapat kecenderungan spesies $S$. virgatus mengakumulasi mikroplastik paling tinggi di ketiga organ yang diamati. Uji Kruskal-Wallis di ketiga spesies ikan menunjukkan hasil yang signifikan pada insang $(\mathrm{P}=0,001)$ dan saluran pencernaan $(\mathrm{P}$ $<0,0001)$, sedangkan pada daging tidak signifikan $(\mathrm{P}=0,054)$. Hasil uji lanjut Dunn's Multiple Comparison menunjukkan kelimpahan mikroplastik tertinggi di insang dan saluran pencernaan ditemukan pada ikan $S$. virgatus dan terendah pada ikan $H$. far dan L. lentjan (Gambar 2). Oleh karena itu, spesies ikan $S$. virgatus mengakumulasi mikroplastik paling tinggi di insang dan saluran pencernaannya dibandingkan spesies ikan lainnya. Akumulasi mikroplastik yang tinggi pada saluran pencernaan $S$. virgatus diduga terkait dengan preferensi makanannya di alam dan ukuran saluran pencernaannya yang panjang. Menurut Amalyah et al. (2019), ikan baronang memiliki daya ramban (grazing) yang tinggi terhadap makroalga
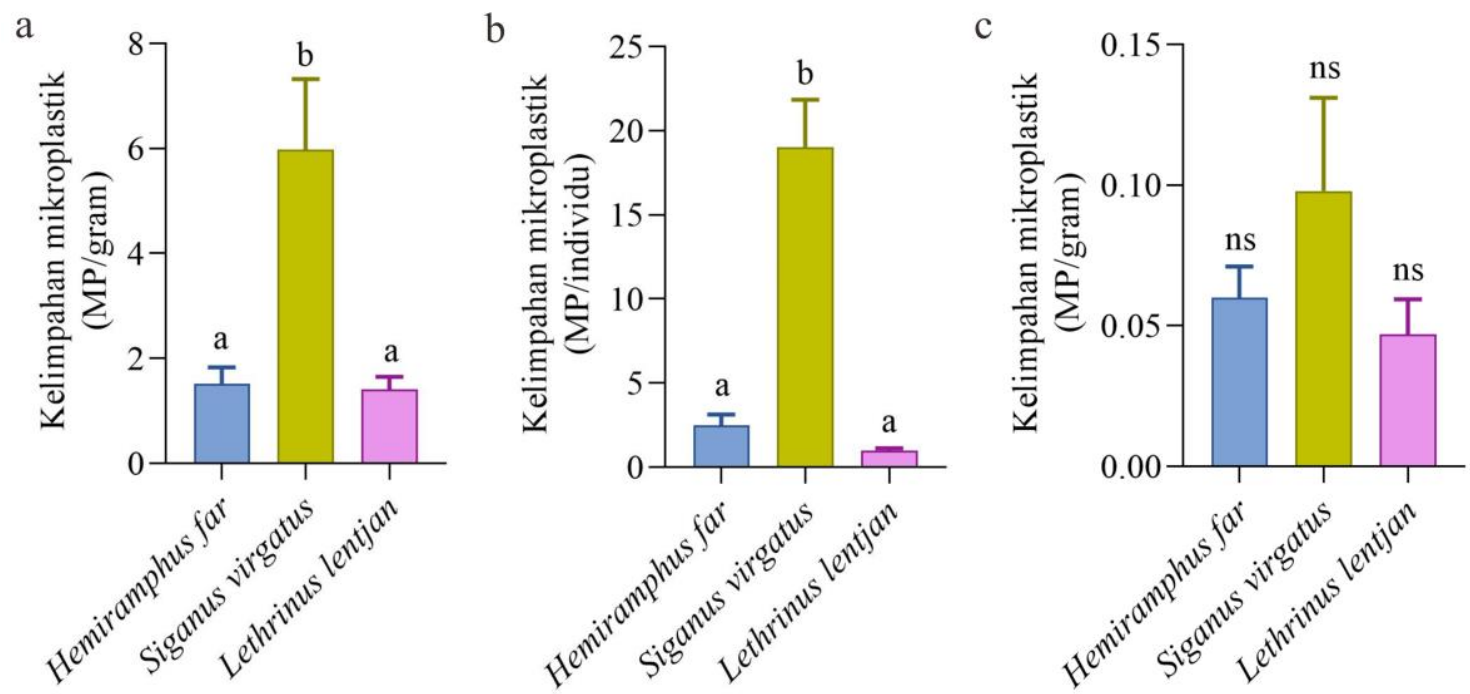

Gambar 2. Kelimpahan mikroplastik organ ikan meliputi (a) insang; (b) saluran pencernaan; dan (c) daging ikan jenis ekonomis penting (huruf berbeda menunjukkan $\mathrm{P}<$ $0,05)$. 
dan merupakan ikan yang rakus. Keberadaan mikroplastik pada jenis makanan spesies ikan ini di alam berupa makroalga dan lamun berpotensi mengalami translokasi ke dalam saluran pencernaan ikan (Gutow et al. 2015; Datu et al. 2019). Selain itu, konsumsi serat yang tinggi dari makanan yang dikonsumsi oleh ikan ini di alam akan membutuhkan waktu yang lama untuk dicerna, sehingga diduga kuat mikroplastik yang ikut tertelan juga akan terakumulasi lebih lama di dalam saluran pencernaan (Sitepu et al. 2018). Akumulasi mikroplastik yang tinggi juga ditemukan di insang ikan baronang, hal tersebut diduga sangat terkait dengan habitatnya di alam. Ikan baronang hidup di dasar perairan (demersal) sehingga menjadikan ikan ini rentan akan akumulasi mikroplastik yang berasal dari sedimen dan air laut (Ferreira et al., 2020).

Keberadaan mikroplastik di insang, saluran pencernaan, dan daging pada ikan $H$. far, $S$. virgatus, dan $L$. lentjan yang ditangkap di perairan Pulau Barranglompo, Makassar telah dibuktikan keberadaannya.
Hal tersebut juga telah dibuktikan pada penelitian sebelumnya dengan spesies ikan berbeda (Tabel 1).

Kelimpahan mikroplastik di insang ikan $S$. virgatus pada penelitian ini lebih tinggi dibandingkan penelitian sebelumnya. Begitupun kelimpahan mikroplastik di saluran pencernaan ikan $S$. virgatus dan $H$. far pada penelitian ini lebih tinggi dibandingkan penelitian sebelumnya. Hal yang berbeda ditemukan pada kelimpahan mikroplastik di daging, kelimpahan tertinggi ditemukan pada ikan Sillago sihama di perairan estuari Musa, Teluk Persia (Abbasi et al., 2018) dan kelimpahan mikroplastik di daging ditemukan pada ketiga spesies ikan di penelitian ini.

Bagaimanapun, perlu ditekankan bahwa membandingkan kelimpahan mikroplastik secara langsung dengan beberapa penelitian masih sulit dikarenakan perbedaan metode ekstraski sampel, perbedaan preferensi setiap spesies ikan, dan jumlah organ yang diamati.

Tabel 1. Kelimpahan mikroplastik pada ikan di beberapa lokasi.

\begin{tabular}{|c|c|c|c|c|c|c|c|c|}
\hline \multirow[b]{2}{*}{ Lokasi } & \multirow[b]{2}{*}{ Spesies } & \multirow[b]{2}{*}{$\mathrm{N}$} & \multirow{2}{*}{$\begin{array}{c}\text { Rata-Rata } \\
\text { Panjang } \\
\text { Total }(\mathrm{cm}) \\
\end{array}$} & \multirow{2}{*}{$\begin{array}{l}\text { Rata-Rata } \\
\text { Bobot } \\
\text { Tubuh (gr) }\end{array}$} & \multicolumn{3}{|c|}{ Kelimpahan Mikroplastik } & \multirow[b]{2}{*}{ Referensi } \\
\hline & & & & & $\begin{array}{c}\text { GI } \\
(\mathrm{MP} / \mathrm{gr})\end{array}$ & $\begin{array}{c}\text { GT } \\
\text { (MP/ind) }\end{array}$ & $\begin{array}{c}\mathrm{FL} \\
(\mathrm{MP} / \mathrm{gr})\end{array}$ & \\
\hline $\begin{array}{l}\text { Estuari Musa, } \\
\text { Teluk Persia }\end{array}$ & Sillago sihama & 17 & 18,6 & 57,2 & 2,75 & 1,3 & 3,2 & $\begin{array}{l}\text { Abbasi et al. } \\
\text { (2018) }\end{array}$ \\
\hline $\begin{array}{l}\text { Estuari } \\
\text { Ciliwung, } \\
\text { Jakarta, } \\
\text { Indonesia }\end{array}$ & Aplocheilus sp. & 15 & 1,75 & - & - & 1,97 & - & $\begin{array}{l}\text { Cordova et } \\
\text { al. }(2020)\end{array}$ \\
\hline Pulau Moorea, & Siganus spp. & 33 & 17 & - & - & 0,15 & - & Garnier et al. \\
\hline Prancis & $\begin{array}{l}\text { Epinephelus } \\
\text { merra }\end{array}$ & 33 & 18 & - & - & 0,39 & - & (2019) \\
\hline $\begin{array}{l}\text { Samudra } \\
\text { Atlantik Timur }\end{array}$ & $\begin{array}{l}\text { Dicentrarchus } \\
\text { labrax }\end{array}$ & 50 & 31 & 343 & 0,8 & 1,3 & 0,4 & $\begin{array}{l}\text { Barboza et } \\
\text { al. }(2020)\end{array}$ \\
\hline Laut & $\begin{array}{l}\text { Trachurus } \\
\text { trachurus }\end{array}$ & 50 & 29 & 228 & 0,7 & 1,0 & 0,7 & \\
\hline Pulau & $\begin{array}{l}\text { Scomber colias } \\
\text { Hemiramphus }\end{array}$ & $\begin{array}{l}50 \\
25\end{array}$ & $\begin{array}{c}37 \\
35.7\end{array}$ & $\begin{array}{l}344 \\
170\end{array}$ & $\begin{array}{c}0,7 \\
1.514\end{array}$ & $\begin{array}{c}1,2 \\
2,480\end{array}$ & $\begin{array}{c}0,6 \\
0,060\end{array}$ & This studv \\
\hline \multicolumn{9}{|c|}{ Barranglompo, far } \\
\hline $\begin{array}{l}\text { Makassar, } \\
\text { Indonesia }\end{array}$ & $\begin{array}{l}\text { Siganus } \\
\text { virgatus }\end{array}$ & 25 & 11,7 & 31,2 & 5,976 & 19 & 0,098 & \\
\hline & $\begin{array}{l}\text { Lethrinus } \\
\text { lentjan }\end{array}$ & 50 & 14,9 & 50,2 & 1,412 & 0,980 & 0,047 & \\
\hline
\end{tabular}




\subsection{Karakteristik dan Jenis Polimer Mikroplastik}

Sebanyak 931 partikel plastik dikumpulkan dari organ insang, saluran pencernaan, dan daging pada ketiga spesies ikan berbeda. Partikel mikroplastik ditemukan pada kisaran ukuran 0,07-5 mm sebesar 83,35\% (776 partikel) dan juga ditemukan partikel mesoplastik pada kisaran ukuran 5,03-22,23 $\mathrm{mm}$ sebanyak 16,65\% (155 partikel). Pada penelitian ini, karakteristik hanya dilakukan pada partikel mikroplastik. Akumulasi mikroplastik di insang pada $H$. far mencapai 56 partikel, $S$. virgatus mencapai 44 partikel, dan L. lentjan mencapai 41 partikel. Pada saluran pencernaan, akumulasi mikroplastik pada $H$. far mencapai 62 partikel, $S$. virgatus mencapai 475 partikel, dan $L$. lentjan mencapai 49 partikel. Pada daging, akumulasi mikroplastik pada $H$. far mencapai 23 partikel, $S$. virgatus dan $L$. lentjan masing-masing mencapai 13 partikel. Hasil pengujian FTIR pada sampel mikroplastik didapatkan empat jenis polimer mikroplastik $(\mathrm{N}=6)$ meliputi polypropylene $50 \%$, polyethylene $16,67 \%$, polyurethane $16,67 \%$, dan polystyrene $16,67 \%$.

Karakteristik warna mikroplastik yang ditemukan di semua organ dari ketiga spesies ikan berbeda didominasi oleh biru (Gambar 3a). Persentase mikroplastik berwarna biru pada ikan $H$. far meliputi $69,64 \%$ pada insang, 61,29\% pada saluran pencernaan, dan $82,60 \%$ pada daging. Pada ikan $S$. virgatus meliputi $50 \%$ pada insang, $33,89 \%$ pada saluran pencernaan, dan $69,23 \%$ pada daging. Pada ikan L. lentjan meliputi $46,34 \%$ pada insang, $57,14 \%$ pada saluran pencernaan, $69,23 \%$ pada daging.
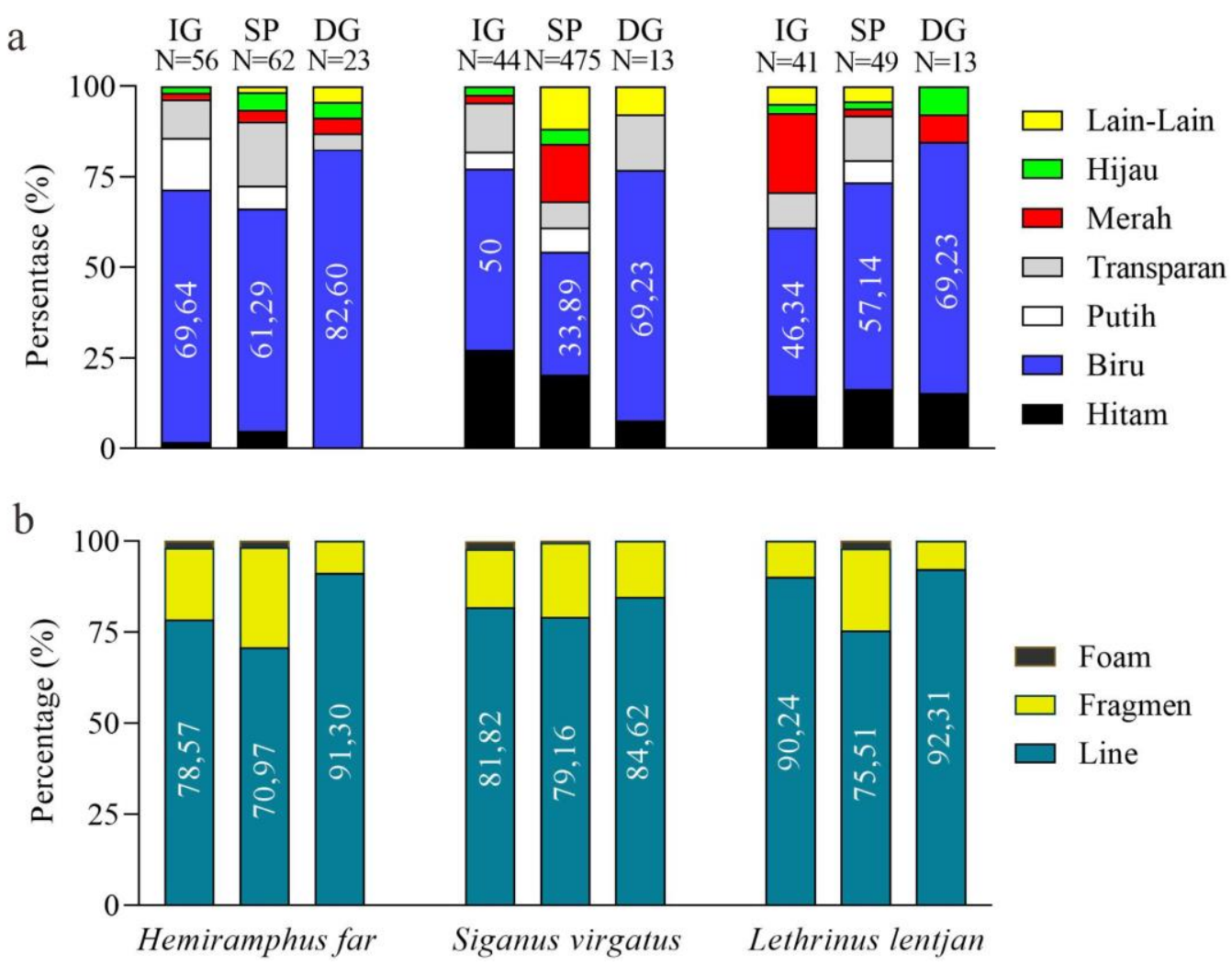

Gambar 3. Perbandingan karakteristik mikroplastik yang terdapat pada masing-masing organ spesies ikan ekonomis penting terdiri dari insang (GI), saluran pencernaan (GT), dan daging (FL) yang dikelompokkan berdasarkan (a-warna; b-bentuk). 
Dominasi warna biru dari mikroplastik juga ditemukan pada penelitian sebelumnya di ikan (Ory et al., 2017; Wicaksono et al., 2020). Selain itu, tingginya kelimpahan mikroplastik berwarna biru pada penelitian ini juga sesuai dengan penelitian sebelumnya di perairan Kepulauan Spermonde Makassar yaitu lamun (Datu et al., 2019), air laut (Afdal et al., 2019), dan sedimen (Tahir et al., 2019a). Setiap jenis ikan diketahui memiliki sensitivitas terhadap warna makanannya dan juga warna lingkungan (Zhang et al., 2015). Penelitian sebelumnya oleh Ory et al. (2017) juga membuktikan bahwa ikan planktivora memiliki selektivitas terhadap mikroplastik biru yang menyerupai pigmen biru dari spesies copepoda yang merupakan mangsa alaminya.

Karakteristik bentuk mikroplastik yang ditemukan di semua organ dari ketiga spesies ikan berbeda yaitu line (dominan), fragmen, dan foam (Gambar 3b). Persentase mikroplastik berbentuk line pada ikan $H$. far meliputi $78,57 \%$ pada insang, $70,97 \%$ pada saluran pencernaan, dan $91,30 \%$ pada daging. Pada ikan $S$. virgatus meliputi $81,82 \%$ pada insang, $79,16 \%$ pada saluran pencernaan, dan $84,62 \%$ pada daging. Pada ikan L. lentjan meliputi 90,24\% pada insang, $75,51 \%$ pada saluran pencernaan, $92,31 \%$ pada daging. Dominasi bentuk line dari mikroplastik juga ditemukan pada penelitian sebelumnya di ikan (Rahmawati \& Patria, 2019; Suwartiningsih et al., 2020; Wicaksono et al., 2020). Dominasi mikroplastik berbentuk line bersumber dari alat tangkap perikanan seperti tali dan jaring, industri tekstil dan serat pakaian sedangkan fragmen bersumber dari botol plastik, cat kapal, dan pecahan plastik yang lebih besar (GESAMP, 2016; Barboza et al., 2019). Bentuk mikroplastik line yang tipis dan ringan memungkinkan untuk mengapung di permukaan laut sehingga ketersediaannya untuk ikan-ikan pelagis sangat melimpah.

Pada Gambar 4a, bentuk line mendominasi di semua spesies pada kisaran ukuran $1-5 \mathrm{~mm}$ pada insang ( $\geq 50 \%$ ), saluran pencernaan (> 75\%) dan daging (> 72\%). Selain itu, bentuk fragmen (Gambar 4b) dengan kisaran ukuran 0,1-0,5 mm mendominasi pada insang $H$. far $(45,45 \%)$ dan S. virgatus $(42,86 \%)$ dan pada L. lentjan didominasi oleh ukuran 1-5 mm (75\%). Pada saluran pencernaan, fragmen berukuran 1-5 mm mendominasi pada $S$. virgatus $(71,13 \%)$ dan L. lentjan (45,45\%), sedangkan pada $H$. far didominasi oleh ukuran 0,1-0,5 mm dan $1-5 \mathrm{~mm}(35,29 \%)$. Pada daging, fragmen berukuran 0,5-1 mm mendominasi pada $H$. far $(100 \%)$ dan L. lentjan (100\%), sedangkan pada $S$. virgatus didominasi oleh ukuran 1-5 $\mathrm{mm}(100 \%)$. Bagaimanapun, ukuran partikel 1-5 mm mendominasi pada organ ikan yang diamati. Dominasi ukuran partikel plastik yang sama pada ketiga spesies ikan diduga diakibatkan oleh adanya kesamaan preferensi ukuran plastik dan juga selektivitas makanannya di alam, serta mekanisme akumulasi mikroplastik pada ikan. Bagaimanapun, identifikasi mikroplastik secara visual masih memiliki limitasi. Mikroplastik yang diamati dengan menggunakan mikroskop stereo dengan perbesaran maksimal $45 x$ hanya memungkinkan mengamati mikroplastik hingga ukuran $\sim 0,05 \mathrm{~mm}$.

Secara keseluruhan, karakteristik mikroplastik yang ditemukan pada organ insang, saluran pencernaan, dan daging ikan didominasi oleh warna biru, bentuk line, dan ukuran 1-5 mm. Adanya kesamaan karakteristik mikroplastik yang ditemukan pada organ-organ ikan memungkinkan dalam menentukan rute atau translokasi mikroplastik ke dalam organ. Karakteristik mikroplastik yang ditemukan pada insang ikan diduga terkait dengan karakteristik mikroplastik di air laut. Hal tersebut didasarkan pada mekanisme filtrasi air laut oleh insang ikan dalam proses respirasi. Mikroplastik dapat tertahan di organ dikarenakan oleh beberapa faktor seperti ukuran mikroplastik, morfologi insang, dan efisiensi alat filtrasi insang (Collard et al., 2017; Barboza et al., 2019). Selain itu, tingginya akumulasi mikroplastik di saluran 
pencernaan ikan yang didukung dengan kemiripan karakteristik mikroplastik pada ketiga spesies ikan mengindikasikan adanya selektivitas ikan terhadap warna makanan yang menyerupai makanan alaminya atau melalui konsumsi mikroplastik secara tidak sengaja dari air laut. Di dalam saluran pencernaan, mikroplastik dapat mengalami fragmentasi menjadi partikel yang lebih kecil sehingga memungkinkan mengalami translokasi ke dalam darah dan daging (Dawson et al., 2018; Weis, 2020).
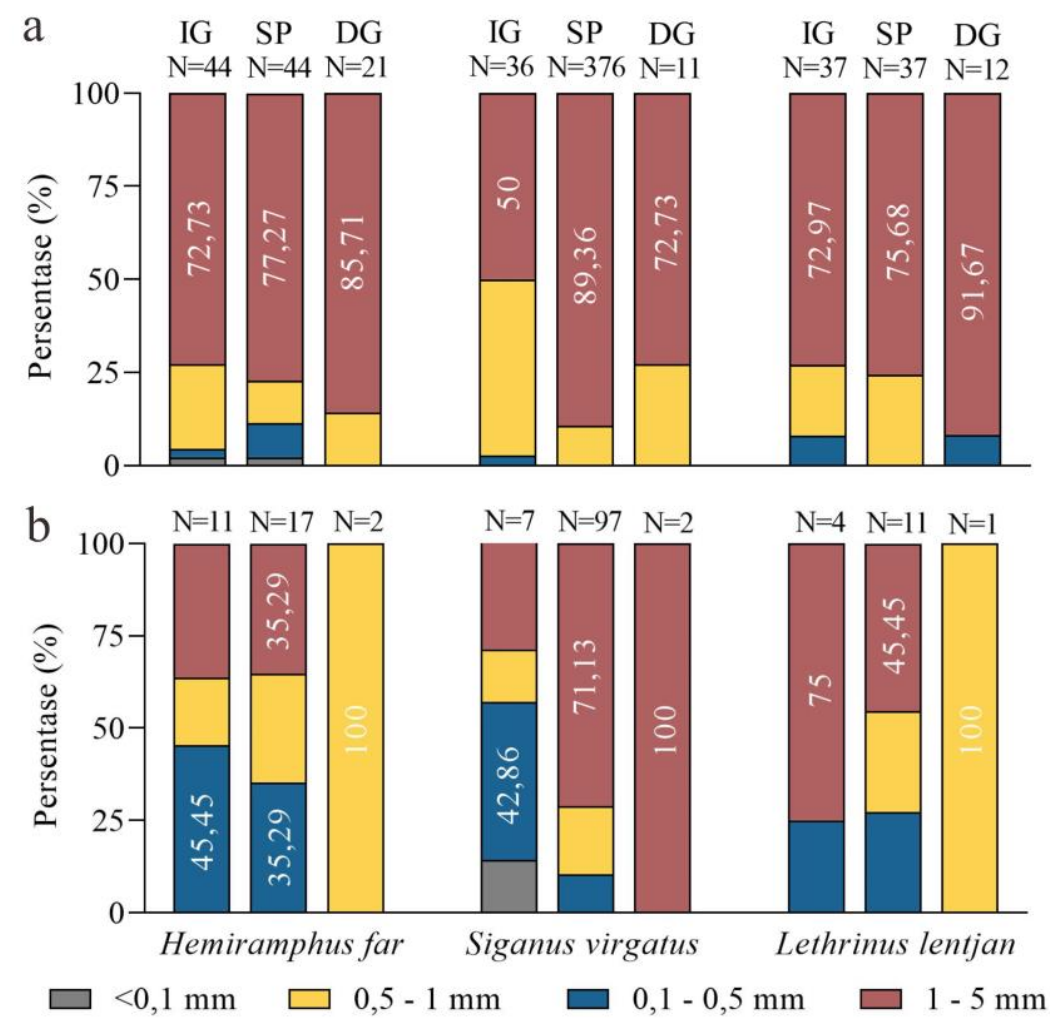

Gambar 4. Ukuran mikroplastik pada setiap organ spesies ikan ekonomis penting spesies ikan ekonomis penting terdiri dari insang (GI), saluran pencernaan (GT), dan daging (FL) dikelompokkan berdasarkan bentuk dominan (a-warna; b-bentuk).

(a)

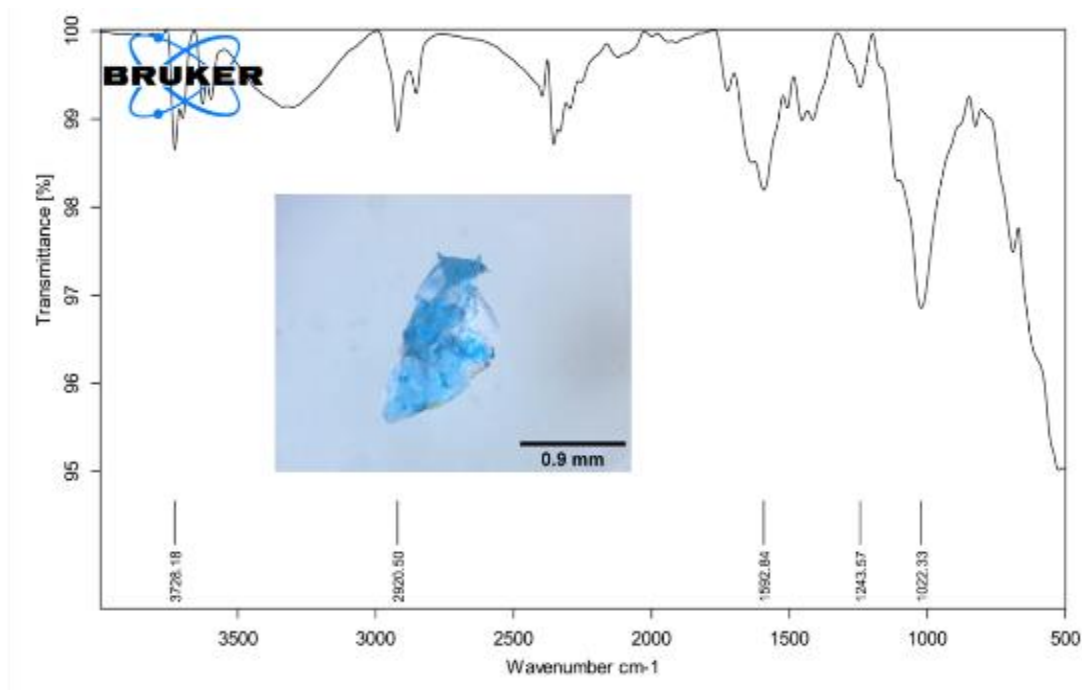


(b)

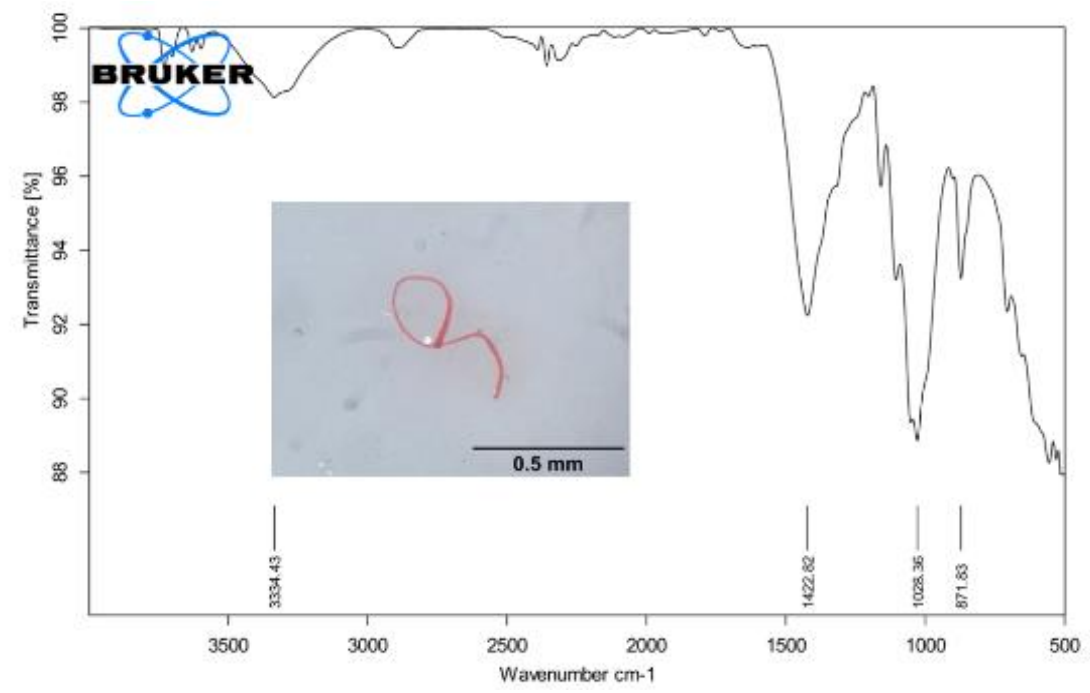

(c)

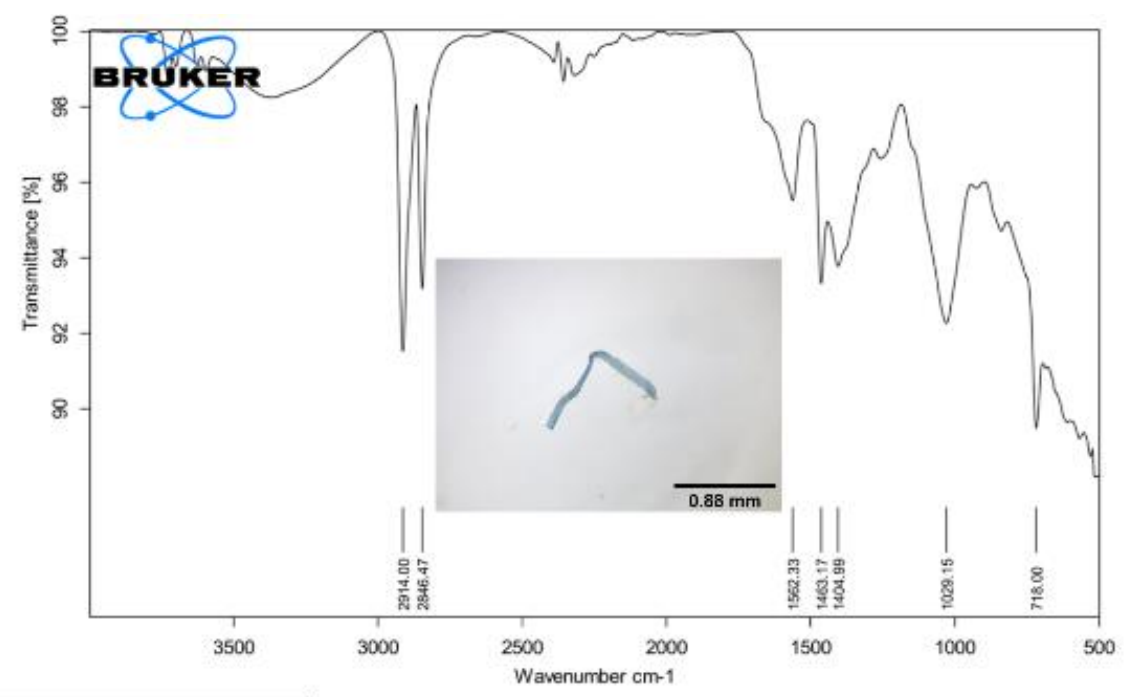

(d)

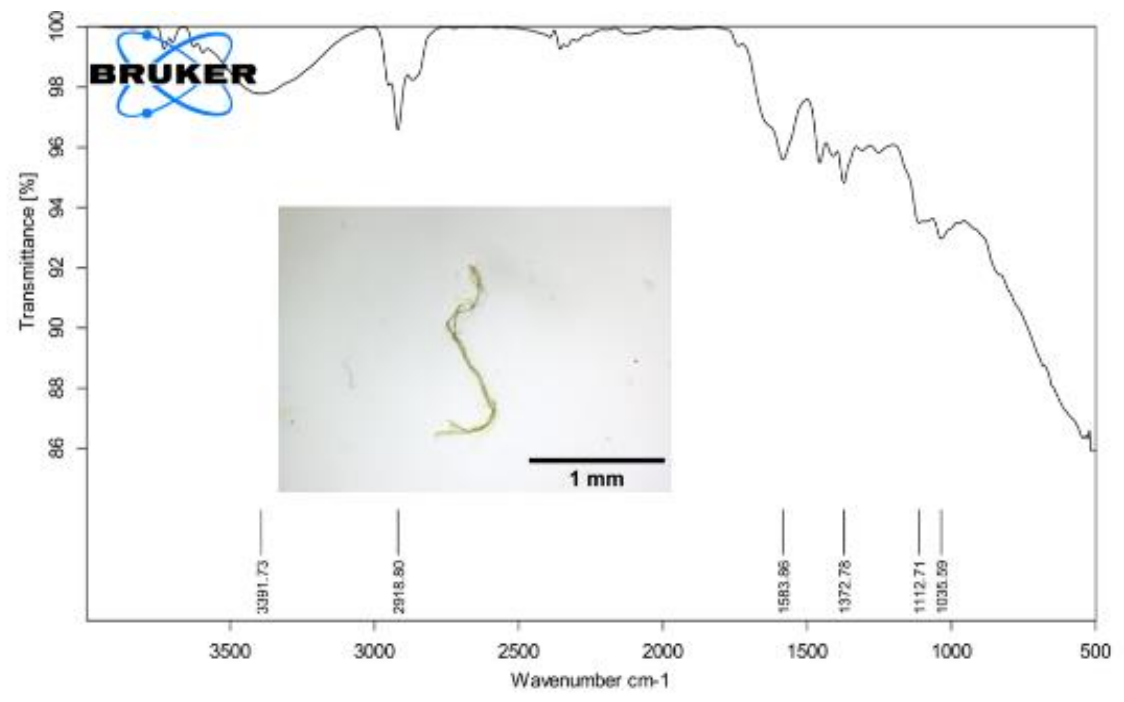

Gambar 5. Hasil spektrum FTIR pada empat jenis partikel mikroplastik. (a) Polyester (PES), (b) Polypropylene (PP), (c) Polyethylene (PE), (d) Polyurethane (PU). 
Kemiripan karakteristik mikroplastik pada saluran pencernaan dan daging pada ikan menguatkan fakta bahwa mikroplastik pada saluran pencernaan telah mengalami translokasi ke dalam daging ikan. Bagaimanapun, penelitian lebih lanjut perlu dilakukan untuk mengetahui mekanisme translokasi mikroplastik dari saluran pencernaan ke dalam daging.

\subsection{Indeks Kesehatan Ikan}

\subsubsection{Indeks Hepatosomatik (IHS)}

Nilai IHS pada penelitian ini dibandingkan antara ikan yang terdeteksi MP dan tidak terdeteksi MP pada organ saluran pencernaannya $(\mathrm{N}=100)$. Pemilihan organ tersebut didasarkan pada kemampuannya dalam mencerna dan menyerap makanan atau senyawa kimia yang kemudian disalurkan ke seluruh tubuh. Selain itu, keberadaan mikroplastik pada saluran pencernaan akan menyebabkan penyumbatan internal dan luka sehingga dapat mengakibatkan terjadinya kelaparan dan malnutrisi pada ikan (Rochman et al., 2015; Ryan, 2016; Baalkhuyur et al., 2018).

Rata-rata IHS ikan $H$. far mencapai $2,198 \pm 0,579$ pada sampel yang terdeteksi MP dan 1,584 $\pm 0,279$ pada sampel yang tidak terdeteksi MP. Nilai IHS ikan $H$. far yang terdeteksi MP secara signifikan lebih tinggi dibandingkan nilai IHS ikan $H$. far yang tidak terdeteksi MP (Independent Sample t-Test, $\mathrm{P}=0,014$ ) (Gambar 6a). Hal yang berbeda ditemukan pada $S$. virgatus, mikroplastik terdeteksi pada $100 \%$ sampel saluran pencernaan dengan IHS rata-rata ikan S. virgatus mencapai $1,828 \pm 0,563$ (Gambar 6b). Pada ikan L. lentjan, rata-rata nilai IHS mencapai $1,033 \pm 0,715$ pada sampel yang terdeteksi MP dan 0,985 $\pm 0,382$ pada sampel yang tidak terdeteksi MP. Hasil uji-t sampel independen pada IHS ikan L. lentjan diperoleh nilai $\mathrm{P}=0,784$, artinya tidak terdapat perbedaan yang signifikan antara IHS L. lentjan pada sampel yang terdeteksi MP dan tidak terdeteksi MP (Gambar 6c).
Berdasarkan hasil Independent Sample t-Test, perbandingan antara IHS ikan yang terdeteksi MP dan tidak terdeteksi MP secara signifikan hanya ditemukan pada ikan H. far. Berbagai faktor secara kompleks dapat menyebabkan perubahan pada IHS ikan seperti adanya penyakit atau senyawa polutan lainnya di lingkungan laut (Morado et al., 2017). Namun, adanya pengelompokan nilai IHS ikan yang terdeteksi MP dan tidak terdeteksi MP dapat menguatkan fakta bahwa mikroplastik secara nyata memberikan efek negatif terhadap kesehatan ikan di alam. Nilai IHS $H$. far yang lebih tinggi pada ikan yang terdeteksi MP dibandingkan ikan yang tidak terdeteksi MP mengindikasikan adanya pengaruh dari retensi dan penyerapan senyawa kimia dari polimer mikroplastik pada saluran pencernaan ikan terhadap detoksifikasi senyawa toksik di organ hati. Menurut Morado et al. (2017), bobot hati pada ikan akan meningkat sebagai akibat dari efek stres akibat polutan di perairan sehingga meningkatkan nilai IHS. Penelitian secara eksperimental oleh Yin et al. (2019) membuktikan bahwa IHS ikan Sebastes schlegelii akan meningkat seiring bertambahnya konsentrasi polystyrene (PS) dan juga meningkatkan produksi lemak dalam hati dibandingkan protein yang menandakan terganggunya metabolisme hati akibat paparan mikroplastik PS.

Hasil yang berbeda ditemukan pada IHS ikan L. lentjan, nilai IHS antara ikan yang terdeteksi MP dan tidak terdeteksi MP menunjukkan hasil yang tidak berbeda nyata. Hal tersebut diduga kuat akibat rendahnya paparan mikroplastik pada saluran pencernaan ikan ini dibandingkan spesies ikan lainnya. Pada ikan S. virgatus, tidak dapat dilakukan perbandingan nilai IHS karena $100 \%$ sampel ikan terdeteksi mikroplastik. Bagaimanapun, kuat dugaan bahwa paparan senyawa kimia dari mikroplastik pada ikan $S$. virgatus memberikan efek negatif terhadap kondisi kesehatan ikan ini, hal tersebut didasarkan 

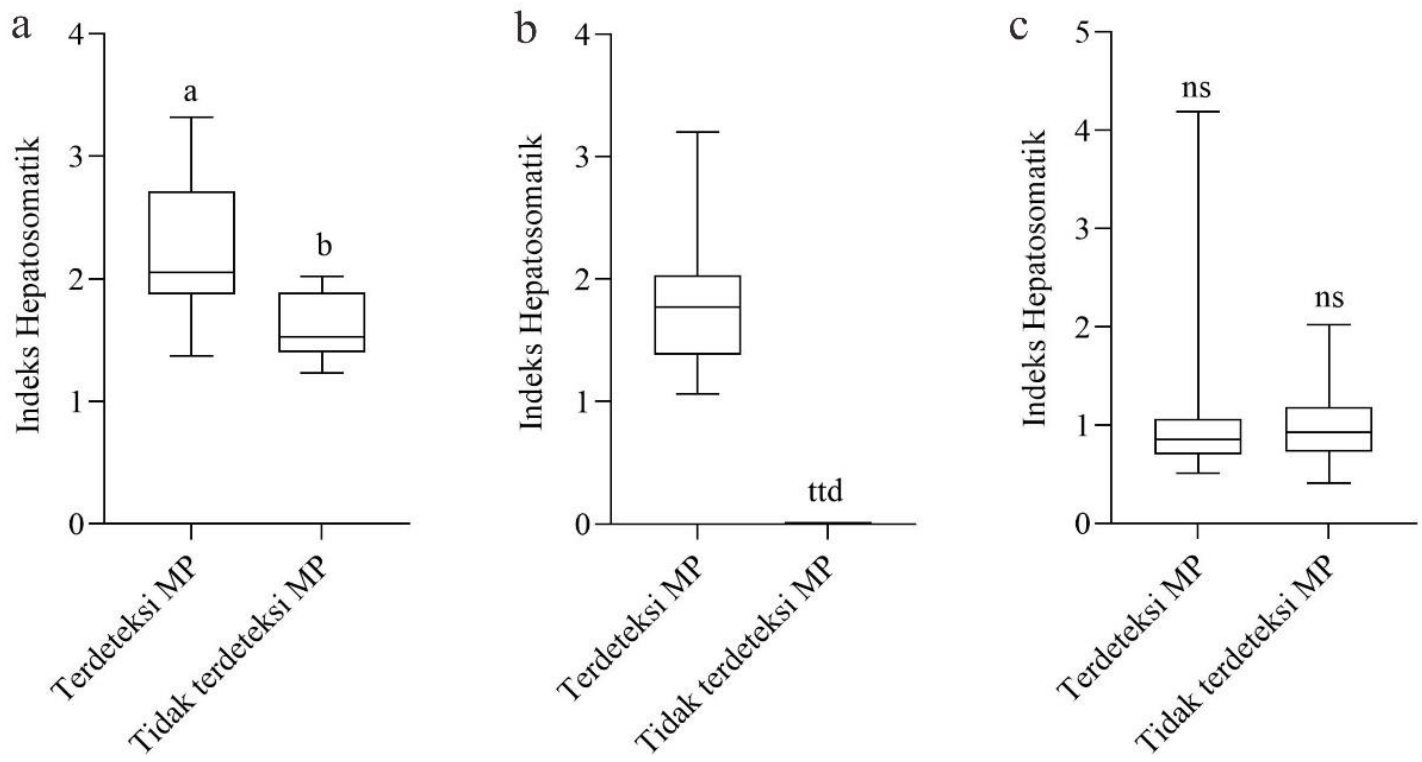

Gambar 6. Penilaian indeks hepatosomatik (HSI) ikan (a) Hemiramphus far; (b) Siganus virgatus; dan (c) Lethrinus lentjan berdasarkan deteksi mikroplastik di saluran pencernaan (nd: tidak terdeteksi); huruf yang berbeda menunjukkan $\mathrm{P}<0,05$.

pada kelimpahan mikroplastik pada saluran pencernaan ikan ini secara signifikan lebih tinggi dibandingkan spesies ikan lainnya.

\subsubsection{Faktor Kondisi Relatif (Kn)}

Faktor kondisi merupakan indikator lain yang digunakan untuk menentukan respons organisme laut terhadap variabel seperti status gizi, efek patogen, dan paparan senyawa kimia toksik. Selain itu, faktor kondisi juga digunakan sebagai biomarker untuk menilai kondisi fisiologis ikan yang dipengaruhi oleh beberapa faktor seperti stres, musim dan ketersediaan makanan di alam. Faktor kondisi dinyatakan dengan koefisien kondisi yang juga dikenal sebagai faktor panjang-berat. Semakin tinggi nilai faktor kondisi maka kondisi ikan semakin baik (Nehemia \& Maganira, 2012; Morado et al., 2017).

Rata-rata nilai $\mathrm{Kn}$ ikan $H$. far mencapai $0,991 \pm 0,105$ pada sampel yang terdeteksi MP dan 2,281 \pm 0,176 pada sampel yang tidak terdeteksi MP. Nilai Kn ikan $H$. far yang terdeteksi MP secara signifikan lebih tinggi dibandingkan nilai Kn ikan $H$. far yang tidak terdeteksi MP (Independent
Sample t-Test, P < 0,0001) (Gambar 7a). Hal yang berbeda ditemukan pada $S$. virgatus, mikroplastik terdeteksi pada $100 \%$ sampel saluran pencernaan dengan Kn rata-rata ikan S. virgatus mencapai 1,002 $\pm 0,073$ (Gambar 7b). Pada ikan L. lentjan, rata-rata nilai $\mathrm{Kn}$ mencapai $1,010 \pm 0,067$ pada sampel yang terdeteksi MP dan 0,987 $\pm 0,051$ pada sampel yang tidak terdeteksi MP. Hasil uji-t sampel independen pada $\mathrm{Kn}$ ikan L. lentjan diperoleh nilai $\mathrm{P}=0,182$, artinya tidak terdapat perbedaan yang signifikan antara $\mathrm{Kn} L$. lentjan pada sampel yang terdeteksi MP dan tidak terdeteksi MP (Gambar 7c).

Berdasarkan hasil Independent Sample t-Test, perbandingan antara Kn ikan yang terdeteksi MP dan tidak terdeteksi MP secara signifikan hanya ditemukan pada ikan $H$. far. Nilai Kn yang lebih rendah pada ikan yang terdeteksi mikroplastik menunjukkan bahwa status kesehatan ikan dalam kondisi buruk sehingga kuat dugaan kondisi ini terjadi akibat retensi dan senyawa kimia mikroplastik. Menurut Critchell \& Hoogenboom (2018), keberadaan mikroplastik pada saluran pencernaan ikan akan mengakibatkan efek kekenyangan dan 

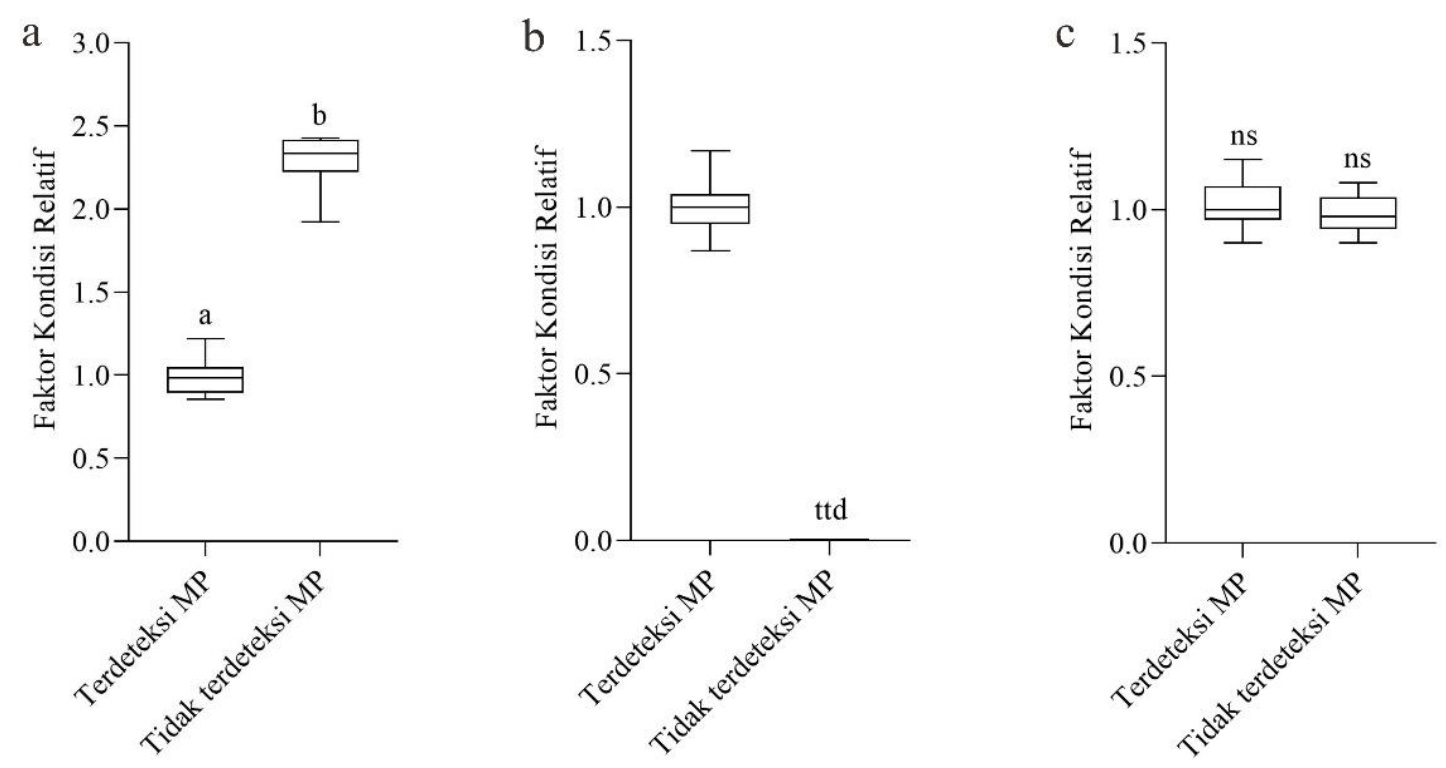

Gambar 7.Penilaian Faktor Kondisi Relatif (Kn) ikan (a) Hemiramphus far; (b) Siganus virgatus; dan (c) Lethrinus lentjan berdasarkan deteksi mikroplastik di saluran pencernaan (nd: tidak terdeteksi); huruf yang berbeda menunjukkan $\mathrm{P}<0,05$.

malnutrisi. Penelitian ini juga membuktikan bahwa tingginya nilai Kn pada ikan $H$. far yang tidak terpapar mikroplastik pada saluran pencernaannya menunjukkan kondisi ikan yang baik. Penelitian secara eksperimental oleh Yin et al. (2019) juga membuktikan bahwa semakin tinggi paparan mikroplastik polystyrene (PS) pada ikan akan menurunkan nilai faktor kondisinya.

Hasil penilaian IHS dan $\mathrm{Kn}$ pada ketiga spesies ikan memiliki tren yang sama. Pada ikan S. virgatus, meskipun pada saluran pencernaan ikan ini ditemukan kelimpahan mikroplastik paling tinggi dibandingkan spesies lainnya, tidak dapat dilakukan perbandingan antara ikan yang terdeteksi dan tidak terdeteksi mikroplastik baik pada nilai IHS maupun Kn dikarenakan tingkat deteksi mikroplastik ditemukan $100 \%$ pada saluran pencernaannya. Meskipun demikian, sangat besar kemungkinan potensi bahaya dari retensi mikroplastik pada ikan S. virgatus terhadap kesehatannya baik dampak secara fisik maupun secara kimia. Potensi bahaya ini didasarkan pada tingginya akumulasi mikroplastik pada $S$. virgatus akibat kebiasaan makannya yang rakus dan juga habitatnya di perairan dasar (demersal). Hal berbeda ditemukan pada ikan $H$. far, retensi mikroplastik pada ikan $H$. far yang terpapar mikroplastik mengakibatkan peningkatan bobot hati yang abnormal yang ditandai dengan nilai IHS yang tinggi dan terjadinya malnutrisi atau kondisi ikan yang buruk akibat penyerapan senyawa racun dari polimer mikroplastik yang ditandai oleh nilai Kn yang rendah. Oleh karena itu, ikan H. far secara ideal berpotensi dijadikan sebagai spesies sentinel pencemaran mikroplastik di perairan laut dikarenakan ikan ini bersifat herbivora dan juga dapat mengakumulasi mikroplastik dengan baik di perairan laut, serta pengaruh retensi mikroplastik terhadap kesehatan ikan $H$. far sangat tergambar dari parameter indeks hepatosomatik dan faktor kondisinya. Sementara fenomena yang sama tidak terlihat pada dua spesies ikan lainnya.

\section{KESIMPULAN}

Penelitian ini telah membuktikan adanya akumulasi mikroplastik pada organ insang, saluran pencernaan, dan daging ikan. Karakteristik mikroplastik yang ditemukan 
didominasi oleh warna biru, bentuk line, dan ukuran 1-5 mm. Akumulasi mikroplastik diduga telah memberikan efek negatif terhadap kondisi kesehatan $H$. far, hal tersebut sangat tergambar dari nilai indeks hepatosomatik dan faktor kondisinya. Keberadaan mikroplastik pada spesies ikan ekonomis penting tentunya memberikan kekhawatiran terhadap keamanan pangan dan potensi bahaya terhadap manusia yang mengonsumsinya. Bagaimanapun, perlu dilakukan penelitian lebih lanjut terkait akumulasi mikroplastik di ketiga organ ikan secara eksperimental di laboratorium dalam keadaan terkontrol dan juga mengkaji dampak mikroplastik terhadap kesehatan manusia.

\section{UCAPAN TERIMA KASIH}

Penulis mengucapkan terima kasih kepada Lembaga Pengelola Dana Pendidikan (LPDP) Kementerian Keuangan Republik Indonesia yang telah membiayai penelitian ini. Selain itu, terima kasih penulis juga ucapkan kepada Dekan Fakultas Ilmu Kelautan dan Perikanan, Universitas Hasanuddin, Makassar yang telah memberikan izin penelitian di Laboratorium Ekotoksikologi Laut.

\section{DAFTAR PUSTAKA}

Abbasi, S., N. Soltani, B. Keshavarzi, F. Moore, A. Turner, \& $\mathrm{M}$. Hassanaghaei. 2018. Microplastics in different tissues of fish and prawn from the Musa Estuary, Persian Gulf. Chemosphere, 205: 80-87. https://doi.org/10.1016/j.chemosphere .2018.04.076

Afdal, M., S. Werorilangi, A. Faizal, \& A. Tahir. 2019. Studies on microplastics morphology characteristics in the coastal water of Makassar City, South Sulawesi, Indonesia. Int. J. Environ. Agric. Biotechnol., 4(4): 1028-1033. https://doi.org/10.22161/ijeab.4421
Ahrendt, C., D.J. Perez-Venegas, M. Urbina, C. Gonzalez, P. Echeveste, M. Aldana, J. Pulgar, \& C. GalbanMalagon. Microplastic ingestion cause intestinal lesions in the intertidal fish Girella laevifrons. Mar. Pollut. Bull., 151: 1-6. https://doi.org/10.1016/j.marpolbul.2 019.110795

Amalyah R., M. Kasim, \& M. Idris. 2019. The grazing of baronang fish (Siganus guttatus) raised with Kappaphycus alvarezii seaweed in the water of Tanjung Tiram, Kabupaten Konawe Selatan. J. Biologi Tropis, 19(2): 309-315. https://doi.org/10.29303/jbt.v19i2.107 5

Avio, C.G., S. Gorbi, \& F. Regoli. 2017. Plastics and microplastics in the oceans: from emerging pollutants to emerged threat. Mar. Environ. Res., 128: $2-11$.

https://doi.org/10.1016/j.marenvres.2 016.05.012

Baalkhuyur, F.M., E.J.A. Bin Dohaish, M.E.A. Elhalwagy, N.M. Alikunhi, A.M. AlSuwailem, A. Rostad, D.J. Coker, M.L. Berumen, \& C.M. Duarte. 2018. Microplastic in the gastrointestinal tract of fishes along the Saudi Arabian Red Sea coast. Mar. Pollut. Bull., 131: 407-415. https://doi.org/10.1016/j.marpolbul.20 18.04.040

Badan Pusat Statistik (BPS). 2019. Kecamatan Ujung Tanah Dalam Angka Tahun 2019. BPS. Makassar. $358 \mathrm{p}$.

Barboza, L.G.A., C. Lopes, P. Oliveira, F. Bessa, V. Otero, B. Henriques, J. Raimundo, M. Caetano, C. Vale, \& Guilhermino. 2019. Microplastics in wild fish from North East Atlantic Ocean and its potential for causing neurotoxic effects, lipid oxidative damage, and human health risks associated with ingestion. Sci. Total 
Environ., 717: 1-14.

https://doi.org/10.1016/j.scitotenv.201 9.134625

Collard, F., B. Gilbert, G. Eppe, L. Roos, P. Compere, K. Das, \& E. Parmentier. 2017. Morphology of the filtration apparatus of three planktivorous fishes and relation with ingested anthropogenic particles. Mar. Pollut. Bull., 116(1-2): 182-191.

https://doi.org/10.1016/j.marpolbul.20 16.12.067

Cordova, M.R., E. Riany, \& A. Shiomoto. Microplastics ingestion by blue panchax fish (Aplocheilus sp.) from Ciliwung Estuary, Jakarta, Indonesia. Mar. Pollut. Bull., 161: 1-9. https://doi.org/10.1016/j.marpolbul.20 20.111763

Critchell, K. \& M.O. Hoogenboom. 2018. Effects of microplastic exposure on the body condition and behavior of planktivorous reef fish (Acanthochromis polyacanthus). PLoS One, 13(3): 1-19.

https://doi.org/10.1371/journal.pone.0 193308

Datu, S.S., Supriadi, \& A. Tahir. 2019. Microplastic in Cymodocea rotundata seagrass blades. Int. J. Environ. Agric. Biotechnol., 4(6): 1758-1761. https://doi.org/10.22161/ijeab.46.21

Dawson, A.L., S. Kawaguchi, C.K. King, K.A. Townsend, R. King, W.M. Huston, \& S.M.B. Nash. 2018. Turning microplastics into nano plastics through digestive fragmentation by Antarctic krill. Nat. Commun., 9(1): 1-8. https://doi.org/10.1038/s41467-01803465-9

Digka, N., C. Tsangaris, M. Torre, A. Anastasopoulou, \& C. Zeri. 2018. Microplastics in mussels and fish from the Northern Ionian Sea. Mar. Pollut. Bull., 135: 30-40. https://doi.org/10.1016/j.marpolbul.20 18.06.063
Ferreira, M., J. Thompson, A. Paris, D. Rohindra, \& C. Rico. Presence of microplastics in water, sediments and fish species in an urban coastal environment of Fiji, a Pacific small island developing state. Mar. Pollut. Bull., 153: 1-9. https://doi.org/10.1016/j.marpolbul.20 20.110991

Foekema, E.M., C.D. Gruijter, M.T. Mergia, J.A.V. Franeker, A.J. Murk, \& A.A. Koelmans. 2013. Plastic in North Sea fish. Environmenrtal Sci. Technol., 47: 8818-8824. https://doi.org/10.1021/es400931b

Fu, Q., X. Tan, S.Ye, L. Ma, Y. Gu, P. Zhang, Q. Chen, Y. Yang, \& Y. Tang. 2020. Mechanism analysis of heavy metal lead captured by natural-aged microplastics. Chemosphere, 270: 19.

https://doi.org/10.1016/j.chemosphere .2020 .128624

Galgani, F. 2015. The Mediterranean Sea: From litter to microplastics. Micro 2015. 53 p.

Garnier, Y., H. Jacob, A.S. Guerra, F. Bertucci, \& D. Lecchini. 2019. Evaluation of microplastic ingestion by tropical fish from Moorea Island, French Polynesia. Mar. Pollut. Bull., 140: 165-170.

https://doi.org/10.1016/j.marpolbul.20 19.01.038

Gonino, G., P. Branco, E. Benedito, M.T. Ferreira, \& J.M. Santos. 2019. Shortterm effects of wildfire ash exposure on behavior and hepatosomatic condition of a potamodromous cyprinid fish, the Iberian barbel Luciobarbus bocagei (Steindachner, 1864). Sci. Total Environ., 665: 226234.

https://doi.org/10.1016/j.scitotenv.201 9.02.108

Gutow, L., A. Eckerlebe, L. Gimenez, \& R. Saborowski. 2015. Experimental evaluation of seaweeds as a vector for 
microplastics into marine food webs. Environmental Science and Technology, 50(2): 915-923. https://doi.org/10.1021/acs.est.5b0243 1

Group of Experts on the Scientific Aspects of Marine Environmental Protection (GESAMP). 2015. Sources, fate and effects of microplastics in the marine environment: a global assessment. Rep. Stud. GESAMP. 96 p.

Group of Experts on the Scientific Aspects of Marine Environmental Protection (GESAMP). 2016. Sources, fate and effects of microplastics in the marine environment: part two of a global assessment. GESAMP. 220 p.

https://doi.org/10.1016/j.scitotenv.201 9.135433

Hossain, M.S., M.S. Rahman, M.N. Uddin, S.M. Sharifuzzaman, S.R. Chowdhury, S. Sarker, \& N.M.S. Chowdhury. 2020. Microplastic contamination in penaeid shrimp from the Northern Bay of Bengal. Chemosphere, 238: 124688-238: 1-9. https://doi.org/10.1016/j.chemosphere .2019 .124688

Law, K.L., N. Starr, T. R. Siegler, J.R. Jambeck, N.J Mallos, \& G.H. Leonard. 2020. The United States' contribution of plastic waste to land and ocean. Science Advances, 6: 1-7. https://doi.org/10.1126/sciadv.abd028 8

Le cren, E. 1951. The length-weight relationship and seasonal cycle in gonad weight and condition in the perch. Br. Ecol. Soc., 20(2): 201-219. https://doi.org/10.2307/1540

Li, J., X. Qu, L. Su, W. Zhang, D. Yang, P. Kolandhasamy, D. Li, \& H. Shi. 2016. Microplastics in mussels along the coastal waters of China. Environ. Pollut., 214: 177-184.

https://doi.org/10.1016/j.envpol.2016. 04.012

Lusher, A.L., N.A. Welden, P. Sobral, \& M.
Cole. 2017. Sampling, isolating and identifying microplastics ingested by fish and invertebrates. Anal. Methods., 9(9): 1346-1360. https://doi.org/10.1039/c6ay02415g

Maes, T., Jel, J.V.D.D. Jel, A.D. Vethaak, M. Desender, V.A. Bendall, M.V. Velzen, \& H.A. Leslie. 2020. You are what you eat, microplastics in porbeagle sharks from the North East Atlantic: Method development and analysis in spiral valve content and tissue. Front Mar Sci., 7(273): 1-17. https://doi.org/10.3389/fmars.2020.00 273

Mandala, W.F. 2016. Barriers and strategy for waste management at Barrang Lompo Island. The Journal of Fisheries Development, 2(2): 61-68. https://jurnal.uniyap.ac.id/jurnal/inde x.php/Perikanan/article/252/242.pdf

Miller, M.E., M. Hamann, \& F.J. Kroon. 2020. Bioaccumulation and biomagnification of microplastics in marine organisms: a review and metaanalysis of current data. PLoS One, 15(10): 1-25. https://doi.org/10.1371/journal.pone.0 240792

Mizraji, R., C. Ahrendt, D. Perez-Venegas, J. Vargas, J. Pulgar, M. Aldana, F.P. Ojeda, C. Duarte, \& C. GalbanMalagon. 2017. Is the feeding type related with the content of microplastics in intertidal fish gut? Mar. Pollut. Bull., 116(1-2): 498500.

https://doi.org/10.1016/j.marpolbul.20 17.01.008

Morado, C.N., F.G. Araujo, \& I.D. Gomes. 2017. The use of biomarkers for assessing effects of pollutant stress on fish species from a tropical river in Southeastern Brazil. Acta. Sci-Biol. Sci., 39(4): 431-439. https://doi.org/10.4025/actascibiolsci. v39i4.34293 
Munno, K., P.A. Helm, D.A. Jackson, C. Rochman, \& A. Sims. 2018. Impacts of temperature and selected chemical digestion methods on microplastic particles. Environmental Toxicology and Chemistry, 37(1): 91-98. https://doi.org/10.1002/etc.3935

Nehemia, A. \& J. Maganira. 2012. LengthWeight relationship and condition factor of tilapia species grown in marine and fresh water ponds. Agric. Biol. J. North Am., 3(3): 117-124. https://doi.org/10.5251/abjna.2012.3. 3.117.124

Nie, H., J. Wang, K. Xu, Y. Huang, \& M. Yan. 2019. Microplastic pollution in water and fish samples around in Nanxun Reef. Sci. Total. Environ., 696: 134022.

https://doi.org/10.1016/j.scitotenv.201 9.134022

Nurdin, N., K. Amri, A.R. Djalil, M.A. As, I. Jaya, \& Agus. 2015. Dynamics of shallow water cover small islands, Spermonde Islands. Maj. Ilm. Globe., 17(2): 105-112.

https://jurnal.big.go.id/index.php/GL/ article/view/221/218

Ory, N.C., P. Sobral, J.L. Ferreira, \& M. Thiel. 2017. Amberstripe scad Decapterus muroadsi (Carangidae) fish ingest blue microplastics resembling their copepod prey along the coast of Rapa Nui (Easter Island) in the South Pacific subtropical gyre. Sci. Total Environ., 586: 430-437.

https://doi.org/10.1016/j.scitotenv.201 7.01.175

Potocka, M., R.C. Bayer, \& M. Potocki. 2019. Plastic pollution affects american lobsters, Homarus americanus. Mar. Pollut. Bull., 138(2019): 545-548. https://doi.org/10.1016/j.marpolbul.20 18.12.017

Rahmawati, N.H.F. \& M.P. Patria. 2019. Microplastics dissemination from fish Mugil dussumieri and mangrove water of Muara Teluknaga, Tangerang, Banten. J. Phys. Conf. Ser., 1282: 1-5.

https://doi.org/10.1088/17426596/1282/1/012104

Rasyid, A., N. Nurdin, A.I. Burhanuddin, \& M. Hatta. 2014. Makassar water oceanography character which connected with fishing potential area of small pelagic fish on east season. $J$. IPTEKS PSP, 1(1): 69-80.

https://doi.org/10.20956/jipsp.v1i1.61

Rochman, C.M., A. Tahir, S.L. Williams, D.V. Baxa, R. Lam, J.T. Miller, F.C. Teh, S. Werorilangi, \& S.J. Teh. 2015. Anthropogenic debris in seafood: plastic debris and fibers from textiles in fish and bivalves sold for human consumption. Sci. Rep., 5(14340): 1-10. https://doi.org/10.1038/srep14340

Rosas-Luis, R. 2016. Description of plastic remains found in the stomach contents of the jumbo squid Dosidicus gigas landed in Ecuador during 2014. Mar. Pollut. Bull., 113(1-2): 302-305. https://doi.org/10.1016/j.marpolbul.20 16.09 .060

Ryan, P.G. 2016. Ingestion of plastics by marine organisms. Handbook of Environmental Chemistry. Springer. $32 \mathrm{p}$.

Selvam, S., K. Jesuraja, S. Venkatramanan, P.D. Roy, \& V.J. Kumari. 2021. Hazardous microplastic characteristics and its role as a vector of heavy metal in groundwater and surface water of coastal south India. J. Hazard. Mater., 402: 123786. https://doi.org/10.1016/j.jhazmat.202 0.123786

Simanjuntak, C.P.H., Noviana, A.K. Putri, M.F. Rahardjo, Djumanto, L.S. Syafei, \& D. Abdillah. 2020. Species composition and abundance of small fishes in seagrass beds of the Karang Congkak Island, Kepulauan Seribu 
National Park, Indonesia. IOP Conf. Ser. Earth Environ. Sci., 404: 1-14. https://doi.org/10.1088/17551315/404/1/012063

Sitepu, F., Suwarni, \& Sudarwati. 2018. Food habits of white-spotted spinefoot (Siganus canaliculatus Park, 1797) in Makassar Strait. J. Pengelolaan Perairairan, 1(1): 6676.

https://journal-

old.unhas.ac.id/index.php/jpp/article/ view/3941/pdf

Suwartiningsih, N., I. Setyowati, \& R. Astuti. 2020. Microplastics in pelagic and demersal fishes of Pantai Baron, Yogyakarta, Indonesia. J. Biodjati, 5(1): 33-49.

https://doi.org/10.15575/biodjati.v5i1. 7768

Tahir, A., M.F. Samawi, K. Sari, R. Hidayat, R. Nimzet, E.A. Wicaksono, L. Asrul, \& S. Werorilangi. 2019a. Studies on microplastic contamination in seagrass beds at Spermonde Archipelago of Makassar Strait, Indonesia. J. Phys. Conf. Ser., 1341(2): 1341: 1-6.

https://doi.org/10.1088/1742-

6596/1341/2/022008

Tahir, A., P. Taba, M.F. Samawi, \& S. Werorilangi. 2019b. Microplastics in water, sediment and salts from traditional salt producing ponds. Glob. J. Environ. Sci. Manag., 5(4): 431-440.

https://doi.org/10.22034/gjesm.2019.0 4.03

United Nations Environment Programe (UNEP). 2016. Marine plastic debris and microplastics-Global lessons and research to inspire action and guide policy change. United Nations Environment Programe, Nairobi. 252 p.

Weis, J.S. 2020. Suggestions for the Future. Water, 12(1475): 1-10. https://doi.org/10.3390/w12051475
Wicaksono, E.A., A. Tahir, \& S. Werorilangi. 2020. Preliminary study on microplastic pollution in surfacewater at Tallo and Jeneberang Estuary, Makassar, Indonesia. AACL Bioflux, 13(2): 902-909. https://www.bioflux.com.ro/docs/202 0.902-909.pdf

World Bank. 2018. Indonesia's Marine Debris Hotspot. Synthesis Report. 49 p.

Yin, L., H. Liu, H. Cui, B. Chen, L. Li, \& F. Wu. 2019. Impacts of polystyrene microplastics on the behavior and metabolism in a marine demersal teleost, black rockfish (Sebastes schlegelii). J. Hazard. Mater., 380: 18.

https://doi.org/10.1016/j.jhazmat.201 9.120861

Zhang, J., H. Guo, Z. Ma, S. Jiang, K. Wu, Y. Li, \& J.G. Qin. 2015. Effects of prey color, wall color and water color on food ingestion of larval orangespotted grouper Epinephelus coioides (Hamilton, 1822). Aquac. Int., 23(6): 1377-1386. https://doi.org/10.1007/s10499-0159890-y

Submitted: 19 February 2021

Reviewed : 10 March 2021

Accepted : 10 July 2021 


\section{FIGURE AND TABEL TITLES}

Figure 1. Map of sampling location at Barranglompo Island, Spermonde Archipelago, South Sulawesi.

Figure 2. Microplastic abundance of fish organs including (a) gill; (b) gastrointestinal tract; dan (c) flesh of economically important fish species (different letters showed the $P<0,05)$.

Figure 3. Comparison of microplastic characteristics found in each organ of economically important fish species consisted of gills (GI), gastrointestinal tract (GT), and flesh (FL) grouped by ( $a$-colour; b-shape).

Figure 4. Microplastic size in each organ of economically important fish species of economically important fish species consisted of gills (GI), gastrointestinal tract $(G T)$, and flesh (FL) grouped by the dominant shape ( $a$-colour; $b$-shape).

Figure 5. Four types of microplastic particles' FTIR spectra result. (a) Polyester (PES), (b) Polypropylene (PP), (c) Polyethylene (PE), (d) Polyurethane (PU).

Figure 6. Hepatosomatic index (HSI) assessment of fish (a) Hemiramphus far; (b) Siganus virgatus; and (c) Lethrinus lentjan based on the detection of microplastics in gastrointestinal tract (nd: not detected); different letters showed the $P<0.05$.

Figure 7. Relative Condition Factor (Kn) assessment of fish (a) Hemiramphus far; (b) Siganus virgatus; and (c) Lethrinus lentjan based on the detection of microplastics in gastrointestinal tract (nd: not detected); different letters showed the $P<0.05$.

Table 1. The abundance of microplastic in fish at several locations. 